\title{
A promise to a court doesn't avoid infringement
}

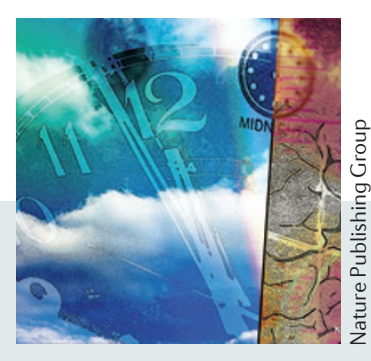

Generics manufacturer Dr Reddy's has been unsuccessful in trying to show that its generic version of the insomnia drug Lunesta (eszopiclone) would not infringe on a patent that protects Lunesta. Dr Reddy's tried to avoid infringing the Lunesta patent by telling a court that it would make a product that would have a narrower range of impurities than the product for which it has sought US Food and Drug Administration (FDA) approval. But the court said this was not a way to avoid patent infringement.

Lunesta is the dextrorotatory isomer of a $5 \mathrm{H}$-pyrrolo[3,4-b]pyrazine compound that is described in its patent (US 6444673) as being "essentially free of its levorotatory isomer". The patent infringement suit arose when Dr Reddy's sought FDA approval to market a version of eszopiclone that contained between $0.3 \%$ and $1.0 \%$ of the levorotatory isomer. This limit was subsequently amended to "not more than $0.6 \%$ " of the levorotatory isomer when the FDA required that the original limit was tightened. This new limit has not yet been approved or denied by the FDA.

The current infringement case then arrived at the US Court of Appeals for the Federal Circuit (CAFC). Because the Lunesta patent did not precisely define the meaning of "essentially free", the Court needed to define this meaning to establish whether Dr Reddy's product would infringe on the patent. Based on the patent prosecution history (the interactions between the patent examiner and the patent applicant), the Court established that "essentially free" equated to less than $0.25 \%$ of the levorotatory isomer. So the version of eszopiclone that Dr Reddy's is seeking FDA approval to market, of not more than $0.6 \%$ (that is, $0.0-0.6 \%$ ), would overlap with the Lunesta patent.

To try to avoid infringement, Dr Reddy's then submitted a declaration to the court (but not to the FDA), saying that because of its internal manufacturing guidelines, it would only produce generic eszopiclone containing $0.3-0.6 \%$ of levorotatory isomer.

But the CAFC said that it is the product that Dr Reddy's has asked the FDA to approve that determines whether infringement will occur, not promises to courts. It added that "Avoid[ing] infringement based on [an] unconventional and unenforceable guarantee ... would be incompatible with the basic principles of patent law".

Sunovion versus Teva et al.: http://www.cafc.uscourts.gov/images/stories/opinionsorders/13-1335.Opinion.9-24-2013.1.PDF

Charlotte Harrison

\section{PATENT ADVISORS}

Daniel M. Becker: Dechert, Mountain View, CA, USA Luke Kempton: Wragge \& Co., London, UK. Leslie Meyer-Leon: IP Legal Strategies, Boston, MA, USA. George W. Schlich: Schlich \& Co., London, UK. John A. Tessensohn: Shusaku Yamamoto, Osaka, Japan. Philip Webber: Dehns, London, UK. 